\title{
HOMLOKMARÁSSAL ELŐÁLLÍTOTT SÍKFELÜLETEK ÉRDESSÉGI ÉS INHOMOGENITÁSI VIZSGÁLATA
}

\author{
Nagy Antal \\ PhD hallgató, Miskolci Egyetem, Gyártástudományi Intézet \\ 3515 Miskolc, Miskolc-Egyetemváros, e-mail: antal.nagy@uni-miskolc.hu
}

\begin{abstract}
Absztrakt
A cikkben acélon szimmetrikus homlokmarással elöállitott felületeken végzett érdességi vizsgálatokról és inhomogenitási elemzésröl számolok be. Ennek során az előtolás és a forgácsoló sebesség hatásainak elemzéseit és megállapitásait közlöm, valamint az inhomogenitási jelenség megfigyelésével foglalkozom.
\end{abstract}

Kulcsszavak: homlokmarás, felületi érdesség, inhomogenitás

\section{Abstract}

In this paper roughness examinations and inhomogeneity analysis on surfaces produced by symmetrical face milling on steel are reported. In doing so, the analyzes and findings of the effects of feed rate and cutting speed, as well as the observation of the inhomogeneity phenomenon are explained.

Keywords: face milling, surface roughness, inhomogeneity

\section{Bevezetés}

Egy megmunkált felület minősége döntő jelentőségü a mechanikai alkatrészek számára, mivel ez a felület integritásának egyik mutatója, és közvetlen hatással van a termék élettartamára és tulajdonságaira [1]. Ezeket a befejező megmunkálás során kell elérni, melynek célja az alkatrészrajzon előírt érdességi és pontossági követelmények teljesítése [2]. Ilyen befejező megmunkálást jelenthet a homlokmarás is, melyet széles körben alkalmaznak síkfelületek létrehozására nagy méretpontossággal, megfelelő síklapúsággal és jó felületi minőséggel [3,4]. Kiterjedt kutatási munkák folynak a müködési követelményeknek megfelelő felületi érdesség elérése érdekében homlokmarásnál is, ezekről számos publikációkban írnak; néhány következtetést az alábbiakban bemutatok [5].

Nagyszámú vizsgálatról olvashatunk, amelyben forgácsolási kísérletekböl származó felületek érdességi eredményeiből tesznek megállapításokat. Ezek során különféle érdességet befolyásoló megmunkálási szempontokat vesznek figyelembe [6]. Általánosságban az érdesség csökken magasabb forgácsoló sebességnél, a stabilabb körülmények miatt. Ezzel ellentétben az alacsonyabb értékek az élrátét kialakulásához és a forgács tördeléséhez vezetnek, amik a felület minőségének romlását okozzák. Az elötolási sebesség, a fogásmélység növelése szintén rosszabb felületet eredményez, és különösen az előtolást tekintik a felületi érdességet leginkább befolyásoló paraméternek [4].

További kutatások mutatnak rá, hogy nemcsak a próbadarabok felületei között, de egy adott felület különböző részein is mérhetők különböző érdességi értékek. Varga és Kundrák megállapította, hogy a szimmetrikus homlokmarásnál a középsíktól távolodva kétirányban az érdesség csökkent [7], és a két oldalon páronként különböző értékek adódtak. A megmunkált felület érdességi eloszlásának kapcsán részletesebb vizsgálatról nincs jelentős publikáció [8]. 
Egy másik gyakori vizsgálati módszer a szimulációs modellek vagy numerikus számítási módszerek alkalmazása, ahol a felületi érdességet elemző vagy numerikus módon határozzák meg, a szerszámgeometria és az adott folyamat kinematikája alapján [3]. Nagy előnye, hogy lehetőséget biztosít a megmunkált felület érdességének megtervezéséhez [2], azonban gyakran nem tudja figyelembe venni a vágás dinamikus hatásait [3]. Kundrák és Felhö több közleményben ismertette azt a saját fejlesztésü CAD-modellt, amellyel különböző geometriájú lapkákkal homlokmart felületeknél összehasonlítja az elméleti és a kísérleti eredményeket, és megadja az elméleti és a tényleges érdességi értékek közötti összefüggést [6]. Gyakran az elméleti-valós értékpárok közel azonosak, az egyes szerszám beállításokra felírható egyenletek az eredmények közti kapcsolatot precízen jellemzik [9].

A fenti megállapításokkal áll célomban rámutatni a jelen cikkben bemutatott vizsgálatok jelentőségére. Az összeállítás a C45 acélon szimmetrikus homlokmarással, eltérő forgácsolási adatokkal készített síkfelületek vizsgálatát mutatja be 2D és 3D felületi érdességi paraméterek révén.

\section{Kísérleti körülmények}

A kísérleteket kollégáimmal együttmüködve egy Perfect Jet MCV-M8 függőleges CNC marógépen végeztük el. A homlokmaró fejben mindig csak egy keményfém váltólapkát szereltünk. A kísérletek során használt szerszámokat és lapkákat a névleges átmérőikkel és élgeometriai adataikkal az 1 . táblázatban foglalok össze.

1. táblázat. Alkalmazott váltólapkák [3]

\begin{tabular}{|c|c|c|c|c|}
\hline Típus & Alak & Lapka kód & Névleges átmérö & \multicolumn{1}{c|}{ Adatok } \\
\hline Rombusz & 0 & R215.44-15T308M-WL & $80 \mathrm{~mm}$ & $\begin{array}{l}\kappa_{\mathrm{r}}=90^{\circ} ; \gamma_{\mathrm{o}}=0^{\circ} ; \alpha_{\mathrm{o}}=11^{\circ} ; \\
\mathrm{r}_{\varepsilon}=0,8 \mathrm{~mm}\end{array}$ \\
\hline Kör & 0 & RCKT1204M0-PM & $68 \mathrm{~mm}$ & $\gamma_{\mathrm{o}}=0^{\circ} ; \alpha_{\mathrm{o}}=7^{\circ}$ \\
\hline
\end{tabular}

A síkfelületek normalizált állapotú C45 ötvözetlen acél (1.0503) próbadarabokon készültek el szimmetrikus homlokmarási beállítással. A forgácsolt felületek szélessége $58 \mathrm{~mm}$, hossza $50 \mathrm{~mm}$ volt. Az alkalmazott forgácsolási adatok $\left(a_{p}[\mathrm{~mm}]\right.$ - fogásmélység, $f_{z}\left[\mathrm{~mm} /\right.$ ford.] - fogankénti elötolás, $v_{c}$ [m/min] - forgácsoló sebesség) vizsgálatonként változtak. Minden esetben csak egy paraméter értékét változtattuk. Az aktuális értékeket a következő szekcióban részletezem.

$\mathrm{Az}$ érdességméréseket AltiSurf 520 3D érdességmérő gépen végeztem el kromatikus konfokális szenzorral. Az eredményeket AltiMap szoftverben értékeltem ki. Az elemzés tárgyául szolgáló érdességi paraméterek vizsgálatonként eltérnek, ezért azokat pontosan a következő szekcióban adom meg.

\section{Mérési eredmények és kiértékelésük}

Az érdességi vizsgálatok során több ízben is elemeztem az előtolás változtatásának hatását. Az egyik esetben [2] a forgácsoló kísérletben az 1. táblázatban jelölt $90^{\circ}$-os rombusz lapkát használtam. Állandó értéken tartottam a forgácsoló sebességet $\mathrm{v}_{\mathrm{c}}=400 \mathrm{~m} / \mathrm{min}$, a fogásmélységet $\mathrm{a}_{\mathrm{p}}=0,4 \mathrm{~mm}$, az előtolás $\mathrm{f}_{\mathrm{z}}=0,1-1,6 \mathrm{~mm} /$ ford. között változtattam öt lépésben. Az érdességmérést az előtolás irányában végeztem el a szimmetriasíkban, és attól azonos $20 \mathrm{~mm}$ távolságokra kétoldalt felvett síkpárban is. Vizsgáltam az iparban leggyakrabban előforduló $2 \mathrm{D}\left(\mathrm{R}_{\mathrm{a}}\right.$ - átlagos érdesség, $\mathrm{R}_{\mathrm{z}}$ - egyenetlenség-magasság) és $3 \mathrm{D}\left(\mathrm{S}_{\mathrm{a}}\right.$ átlagos érdesség, $\mathrm{S}_{\mathrm{z}}$ - maximális magasság) paramétereket egyaránt, a mérések során az előbbiekhez a 
vonatkozó ISO4288:1998 szabványban jelölt mérési hosszokat, a 3D mérés során egységesen 2,5×2,5 $\mathrm{mm}^{2}$ területeket állítottam be. Megállapítottam, hogy valamennyi vizsgált érdességi érték növekedett az előtolás növelésére. A legkisebb fogankénti elötolásnál a síkokban mért értékek között alig volt különbség, de $\mathrm{f}_{\mathrm{z}}$ növelésére a különbségek nagyobbak lettek. Alacsonyabb előtolásnál a szimmetriasíkbeli mért értékek voltak a legkisebbek a síkok közül, azonban azt növelve ez a viszony éppen megfordult. Ez mutatja azt, hogy nem minden esetben elegendő csak a szimmetriasíkban mérni az érdességet, ahol elméletileg maximális az $R_{a}$ és $R_{z}$ is. A felületek leképezései (1. ábra) jól tükrözik a szerszámél alakját és a kinematikai viszonyokat. A középsíkban csak az előtolási irányra merőleges élnyomok jelennek meg, a szélső oldalakon láthatók az előre- és a visszafutó élek karcnyomai egyaránt. $A z R_{a}$ és $R_{z}$ paraméterekröl megállapítható, hogy az előtolás növelésével az érdességi értékek szinte lineárisan növekednek. A síkhármasban mért értékek összehasonlítása során azt tapasztaltam, hogy kis elötolásnál azok közel azonosak, $\mathrm{f}_{\mathrm{z}}$ értékét növelve a különbségek egyre nagyobbak. Emellett, bár elméletileg a középsíktól azonos távolságra azonosak lennének kétoldalt az érdességi értékek, ez a kísérletek során nem igazolódott, ugyanis a szerszámélnek a munkadarabba való belépési oldalán nagyobb értékek adódtak. Ennek oka a középsík által elválasztott ellen- és egyenirányú marás váltakozása. A 3D érdességi paraméterek hasonló változásokat mutattak.

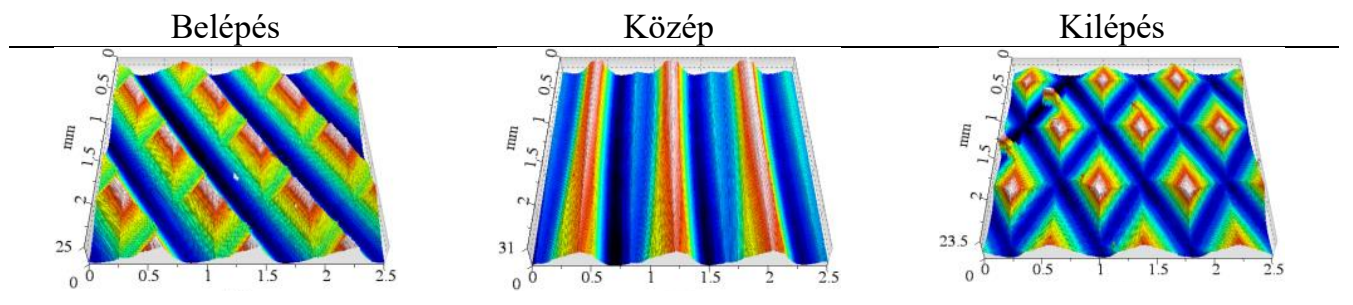

1. ábra. Érdességi topográfia $\left(f_{z}=0,8 \mathrm{~mm} /\right.$ ford. $)$ [5]

Ugyanúgy az előtolás hatását vizsgálta Kundrák és társai, ahol az 1. táblázatban szereplő körlapkát használták [4]. Az elötolásnak ötféle értéket állítottak be $\mathrm{f}_{\mathrm{z}}=0,1 \ldots 0,8 \mathrm{~mm} /$ ford. között, $a z \mathrm{a}_{\mathrm{p}}=0,8 \mathrm{~mm}$ és $\mathrm{v}_{\mathrm{c}}=200 \mathrm{~m} / \mathrm{min}$ nem változott. A felületeken az elözővel megegyező háromsíkos mérési rendszert alkalmazták. Az átlagos érdességek értékei közül $\mathrm{R}_{\mathrm{a}}$ fokozatosan növekedett az előtolással együtt, $\mathrm{S}_{\mathrm{a}} \mathrm{a}$ kisebb előtolásoknál alig változott, majd meredeken emelkedett. Páronként ugyanez a tendencia volt megfigyelhető $R_{z}$ és $S_{z}$ esetében is. Az elötolás növelése során a szimmetriasíkban emelkedett mindegyik vizsgált érdességi érték a legnagyobb mértékben, a három sík közül. Továbbá beállításonként változott a síkok közti értékek különbsége is. Ennek során az $R_{a}$ és $S_{a}$ értékeit tekintve az eltérések $f_{z}=0,3$ $\mathrm{mm} /$ ford. esetén voltak minimálisak, vagyis az érdességi profil ebben az esetben lett a leghomogénebb a kísérletsorozatban. Az érdességi értékek növekedését és az érdességi profil alakját közvetlenül befolyásolta az eljárás kinematikája, mivel a nagyobb elötolás nagyobb szomszédos hornyok közötti távolsághoz és nagyobb profilmagassághoz vezetett. A legkisebb előtolásnál a felület kevésbé simának tünt, ahol a felület egyenetlenségei összehasonlíthatók voltak a barázdák méreteivel, míg a nagyobb előtolásoknál a barázdák mélyebbé váltak, megnőtt a köztük lévő távolság is, a kettőt kevésbé lehetett összevetni.

Egy másik tanulmányban a forgácsoló sebesség hatásának vizsgálatával foglalkozott Nagy és Kundrák [6]. A $90^{\circ}$-os rombusz lapkát használták, az $\mathrm{f}_{\mathrm{z}}=0,4 \mathrm{~mm} /$ ford. és $\mathrm{a}_{\mathrm{p}}=0,8 \mathrm{~mm}$ állandó értékek mellett a forgácsoló sebességnek $\mathrm{v}_{\mathrm{c}}=100 \ldots 500 \mathrm{~m} / \mathrm{min}$ tartományban öt különböző értéket állítottak be. A mérések során öt párhuzamos mérési síkot alkalmaztak, a középsőt a szimmetriasíkra igazítva, azokat egymástól $10 \mathrm{~mm}$ távolságra felvéve. Az elemzett $R_{\mathrm{a}}$ és $\mathrm{R}_{\mathrm{z}}$ értékek a forgácsoló sebesség növelésére elöször hirtelen csökkentek, majd gyakorlatilag változatlanok maradtak. Itt is a középsíkban találták a 
legnagyobb érdességet, és azok a távolsággal arányosan csökkentek. Az érdességi értékek a $\mathrm{v}_{\mathrm{c}}=500$ $\mathrm{m} /$ min sebességnél mutatták a szélső oldalaknak a középsíktól való maximális eltéréseit, valamint a beés kilépő oldalsíkok közötti legnagyobb különbségeket a legalacsonyabb sebességnél tapasztalták, vagyis a legnagyobb felületi inhomogenitás a legkisebb vizsgált sebességgel készült el [1]. A szélső oldalakon kapott értékek közti különbséget itt is megfigyelték, amelyek a szerszámél belépési oldalán nagyobbak voltak, ahol ellenirányú marás történt. A 3D paramétereknél $\left(S_{a}, S_{z}\right)$ ugyanezek a megfigyelések voltak jellemzök. A profilgörbék és a topográfiai leképezések azt mutatták, hogy a szerszámél lenyomatai jól láthatók voltak, a nagyobb sebességek sokkal simább felületeket eredményeztek a marás stabilabb körülményei révén, azok mintázatai meglehetősen szabályosak voltak [1].

Már korábban is - ahogy a fenti publikációkban - megfigyelték, hogy egy adott felületen belül is eltérhetnek az érdességi értékek. Ez a felület inhomogenitását jelenti, amely az érintkező felületpárok kopás és/vagy tribológiai elemzéséhez jó kiindulópont lehet, ezért célzottan ezt is vizsgálta Nagy és Kundrák [8]. Ennek során egy $\mathrm{v}_{\mathrm{c}}=300 \mathrm{~m} / \mathrm{min}, \mathrm{a}_{\mathrm{p}}=0,8 \mathrm{~mm}$ és $\mathrm{f}_{\mathrm{z}}=0,3 \mathrm{~mm} /$ fordulattal szimmetrikusan homlokmart felületen elemezték annak $2 \mathrm{D}$ érdességét egy $5 \times 5$ részes felosztásban (2. ábra). A vizsgált paraméterek $\left(\mathrm{R}_{\mathrm{a}}, \mathrm{R}_{\mathrm{z}}, \mathrm{R}_{\mathrm{mr}}\right.$ - relatív hordozóhossz) közül az átlagos érdesség térképdiagramjait [8] szemléltetem a 2. ábrán. Ezeken jól látható, párhuzamos és merőleges mérési irányok esetében egyaránt, hogy a felület más-más pontján az érdesség értékei nagyon eltérőek lehetnek. $A z R_{a}$ és $R_{z}$ értékei az egyes mérési irányokban hasonló jellemzőket mutattak. Azonban míg az $R_{\mathrm{z}}$ paraméter legnagyobb értéke a szimmetriasíkban volt mérhető az előtolás irányával párhuzamosan vizsgálva, amely összhangban áll azzal, hogy a szerszámél által kialakított barázdák ezen a felületrészen a legnagyobb távolságra vannak egymástól, addig az $\mathrm{R}_{\mathrm{a}}$ maximumát ugyanilyen irányban a $\mathrm{D}$ síkban mérték. A középsíktól egyenlő távolságokra lévő síkpárok értékei minimálisan tértek el, amit az ellen- és egyenirányú marás váltakozásával indokoltak. A számozott pontok közt az oldalsó (A és E) síkokban kismértékü volt az értékek szórása, a középsíkban találták a legnagyobb eltéréseket.

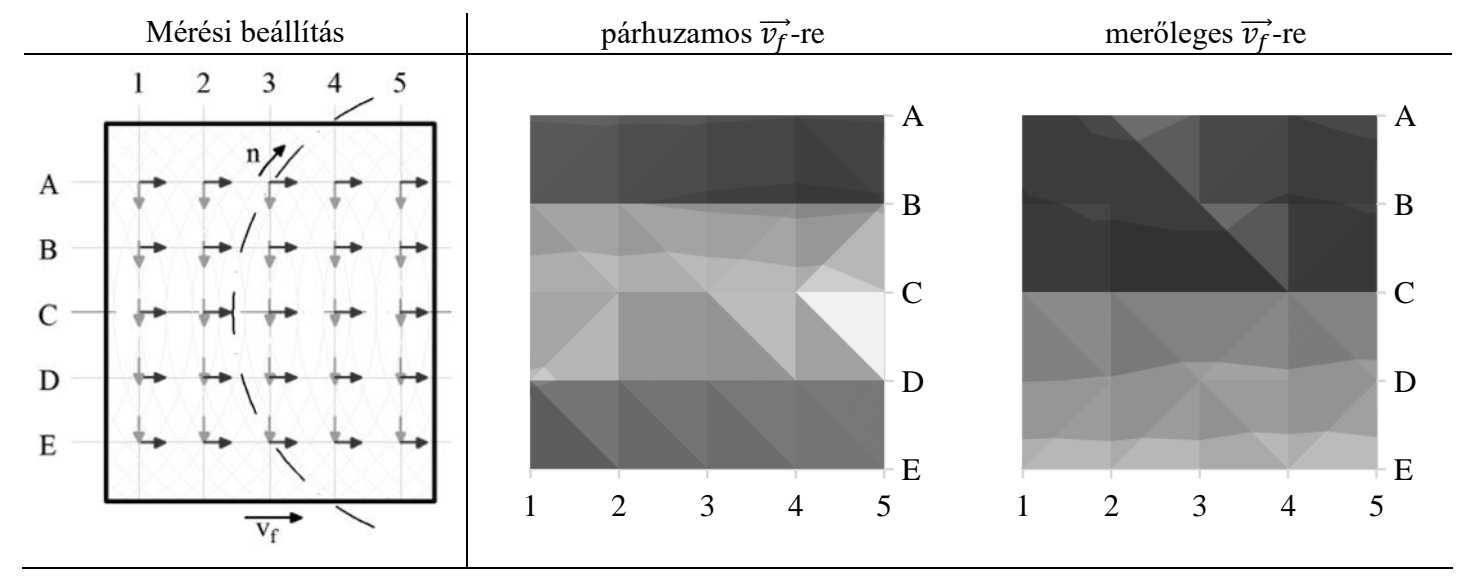

2. ábra. Mérési beállitás és Ra értékeinek érdességi térképdiagramjai [8]

A felületi érdességi paraméterek meghatározásával foglalkozó publikációk többsége nem indokolja az érdességmérő müszeren beállított értékek kiválasztását. A szakirodalmi áttekintés [10] arra is rámutatott, hogy a topográfiákat különböző módon vizsgálják a mért területek nagysága, a mérési beállítások és a kiértékelések szempontjából, így a megmunkált felületek pontos összehasonlítása nem lehetséges. Ezért az érdességmérési beállítási lehetőségek hatását vizsgáltam [10] a 3D érdességi paraméterek leggyakrabban értékelt mérőszámaira, ezek az $S_{\mathrm{a}}, \mathrm{S}_{\mathrm{z}}, \mathrm{S}_{\mathrm{q}}$ (simasági mérőszám), $\mathrm{S}_{\mathrm{sk}}$ (ferdeség) és $\mathrm{S}_{\mathrm{ku}}$ (lapultság) voltak. Ennek során változtattam a mérési sebességet és a mért pontok közötti távolságot. 
Az ehhez felhasznált próbadarab szimmetrikus homlokmarással, az 1. táblázatban szereplő rombusz alakú váltólapkával, valamint $\mathrm{v}_{\mathrm{c}}=300 \mathrm{~m} / \mathrm{min}, \mathrm{a}_{\mathrm{p}}=0,8 \mathrm{~mm}$ és $\mathrm{f}_{\mathrm{z}}=0,3 \mathrm{~mm}$ /fordulattal készült el. Elöször a mérési sebességet $\mathrm{v}_{\mathrm{x}}=200 \ldots 1000 \mu \mathrm{m} / \mathrm{s}$ közt változtatva, a szimmetriasíkban megfigyeltem, hogy ebben a tartományban az érdességi mérőszámok eredményeinek szórása kicsi, 4,5\% alatti volt. Az $\mathrm{S}_{\mathrm{z}}, \mathrm{S}_{\mathrm{sk}}$ és $\mathrm{S}_{\mathrm{ku}}$ értékei nagyobb sebességeknél csökkentek, azonban az $S_{\mathrm{a}}$ és $S_{\mathrm{q}}$ értékei véletlenszerü helyeket foglaltak el a vizsgált zónában. Globálisan a nagyobb sebességek $(700 \ldots 1000 \mu \mathrm{m} / \mathrm{s})$ közül bármilyen értéket használva minimális a hiba lehetősége. Ezután az előtolás irányára merőlegesen felvett pontok közti távolság hatását vizsgáltam három párhuzamos síkban, ahol a felvett értékek $\mathrm{Y}=1 . .25 \mu \mathrm{m}$ között voltak. Itt megfigyeltem, hogy a felületen az oldalsó területek értékpárjai hasonlók, de a középsíktól jelentősen eltérők voltak, azonban az értékek éppen az utóbbinál változtak a legkisebb mértékben. Az érdességi értékek változásainak jellege a távolság függvényében véletlenszerü volt. Mindent összevetve azt tapasztaltam, hogy az 5 és $15 \mu \mathrm{m}$ közötti táv beállítása mellett a legkisebb hibával érhetők el az eredmények. Végül elemezve az előtolással párhuzamos irányú pontsürüség hatását $\mathrm{X}=1 \ldots 7 \mu \mathrm{m}$ tartományban - szintén a felület három részletén - megállapítottam, hogy a mért értékek változásai monoton csökkentek a távolság növelésére. Az $S_{\mathrm{sk}}$ és $S_{\mathrm{ku}}$ értékei alig változtak, így ezen paraméterek alapján a vizsgált tartományon belül bármilyen ponttáv beállítható minimális hiba mellett. $A z S_{q}, S_{a}$ és $S_{z}$ értékeit illetően a kisebb értékeknél, az 1 és $3 \mu \mathrm{m}$ közti tartományban tapasztaltam kis különbséget az értékek között, így ezen tartomány bármely értéke használható csekély eltéréssel.

\section{4. Összefoglalás}

A cikkben bemutatásra kerültek a korábbi önálló és társszerzős kutatómunkáim publikációs eredményei, amelyeknek körülményeiről és következtetéseiröl számoltam be. Az észrevételeket, tapasztalatokat röviden összefoglalom.

Az előtolás hatásának vizsgálata során azt tapasztaltuk, hogy az érdesség az előtolással együtt növekedett, ezek közül az $R_{a}$ és $R_{z}$ értékei szinte lineárisan változtak. Nagyobb elötolásnál a felületrészek érdességi értékei közt nagyobbak voltak a különbségek, illetve azok a szimmetriasíkban emelkedtek a legnagyobb mértékben. Az eredmények csak egy bizonyos elötolás érték felett igazolják azt az elméletet, miszerint a szimmetriasíkban mérhető a maximális érdesség. A felület szélső oldalainak értékei különbséget mutattak, ahol ellen- vagy egyenirányú marás történt. A 3D érdességi paraméterek változásai összhangban voltak a megfelelő vonalmenti párjaikkal.

A forgácsoló sebesség növelésére az érdesség csökkenése egy adott érték felett jelentéktelen mértékü volt. A középsíkban mértük a legnagyobb érdességet, attól távolodva az értékek csökkentek. A szélső oldalak közti maximális eltérést a legalacsonyabb vizsgált sebességnél tapasztaltuk. A 3D paraméterek azonos jelleget mutattak. A grafikus mérési eredmények a nagyobb sebességeknél sokkal simább felületeket mutattak, a mintázatok meglehetősen szabályosak voltak.

Egy homlokmart felület inhomogenitását mutatták az érdességi térképdiagramok a felület pontjai közti jelentős eltérésekkel. Az $R_{a}$ és $R_{z}$ értékei az egyes mérési irányokban hasonló jellemzőket mutattak. $A z R_{z}$ paraméter legnagyobb értéke a szimmetriasíkban volt mérhetö, ami nem volt igaz az $R_{a}$ értékeinél. A középsíktól azonos távolságokban mért értékpárok eltérései az ellen- és egyenirányú marás váltakozásával indokolhatók.

Az érdességmérés beállítási lehetőségei a vizsgált érdességi paraméterekre maximum 5\%-os eltérést mutattak. A mérési sebességet növelve $S_{\mathrm{z}}, S_{\mathrm{sk}}$ és $S_{\mathrm{ku}}$ csökkent, $S_{\mathrm{a}}$ és $S_{\mathrm{q}}$ értékei véletlenszerüen változtak. Általánosságban a nagyobb sebességek eredményeztek minimális értékhibákat. Az előtolás irányára merőlegesen mért pontsürüség az érdességi értékek véletlenszerü változását okozta. Az oldalsó felületrészek értékei páronként hasonlók voltak, de nagymértékben eltértek a középsíkban mérttől, ahol a legkisebb 
mértékủ változás mutatkozott a táv függvényében. A párhuzamos irányú pontsürüség csökkentése a mért értékek csökkenését vonta maga után. Bár az $S_{\mathrm{sk}}$ és $S_{\mathrm{ku}}$ értékei az utóbbinál alig változtak, ezen kívül mindkét irányban a nagyobb pontsürüség mutatott minimális érdességi eltéréseket.

\section{Köszönetnyilvánítás}

A cikkben ismertetett kutató munka az EFOP-3.6.1-16-2016-00011 jelủ „Fiatalodó és Megújuló Egyetem - Innovatív Tudásváros - a Miskolci Egyetem intelligens szakosodást szolgáló intézményi fejlesztése" projekt részeként - a Széchenyi 2020 keretében - az Európai Unió támogatásával, az Európai Szociális Alap társfinanszírozásával valósul meg.

\section{Irodalom}

[1] Kundrak, J., Nagy, A., Markopoulos, A. P., Karkalos, N. E.: Investigation of surface roughness on face milled parts with round insert in planes parallel to the feed at various cutting speeds, Rezanie I Instrumenty V Tekhnologicheskih Sistemah 91 (2019) pp. 87-96.

https://doi.org/10.20998/2078-7405.2019.91.09

[2] Nagy, A.: Homlokmart felület érdessége az elötolás és a forgácsarány változtatásának hatására rombusz alakú lapka alkalmazásával, Multidiszciplináris Tudományok: A Miskolci Egyetem Közleménye 9 No.2 (2019) pp. 84-89. https://doi.org/10.35925/j.multi.2019.2.12

[3] Felhö, C., Nagy, A., Kundrák, J.: Effect of shape of cutting edge on face milled surface topography, 2020 Proceedings of the International Symposium for Production Research 2019, Wien, Austria, pp. 525-534. https://doi.org/10.1007/978-3-030-31343-2_46

[4] Kundrák, J., Nagy, A., Markopoulos, A. P., Karkalos, N. E., Skondras-Giousios, D.: Experimental study on surface roughness of face milled parts with round insert at various feed rates, Rezanie I Instrumenty V Tekhnologicheskih Sistemah 92 (2020) pp. 96-106.

https://doi.org/10.20998/2078-7405.2020.92.11

[5] Kundrak, J., Nagy, A.: Investigation of surface roughness characteristics of face milling, Rezanie I Instrumenty V Tekhnologicheskih Sistemah 90 (2019) pp. 63-72.

[6] Nagy, A., Kundrak, J.: Effect of cutting speed on surface roughness: face milling of steel with a parallelogram insert, 2019 MultiScience - XXXIII. microCAD International Multidisciplinary Scientific Conference, Miskolc-Egyetemváros, Magyarország, Paper: D1-4, pp. 1-10. https://doi.org/10.26649/musci.2019.090

[7] Kundrak, J., Nagy, A., Markopoulos, A. P., Karkalos, N. E.: Investigation of surface roughness on face milled parts with round insert in planes parallel to the feed at various cutting speeds, Rezanie I Instrumenty V Tekhnologicheskih Sistemah 91 (2019) pp. 87-96.

https://doi.org/10.20998/2078-7405.2019.91.09

[8] Nagy, A., Kundrák, J.: Changes in the values of roughness parameters on face-milled steel surface, Rezanie I Instrumenty V Tekhnologicheskih Sistemah 92 (2020) pp. 85-95.

https://doi.org/10.20998/2078-7405.2020.92.10

[9] Nagy, A., Krucsai, Á.: Aluminium ötvözet homlokmarással megmunkált felületi érdességének változása az elötolás függvényében, Multidiszciplináris Tudományok: A Miskolci Egyetem Közleménye 9 No.2 (2019) pp. 8-13. https://doi.org/10.35925/j.multi.2019.2.2

[10] Nagy, A.: Influence of measurement settings on areal roughness with confocal chromatic sensor on face-milled surface, Rezanie I Instrumenty V Tekhnologicheskih Sistemah 93 (2020) pp. 65-75. https://doi.org/10.20998/2078-7405.2020.93.08 